\title{
Front Matter: Volume 7769
}

, "Front Matter: Volume 7769," Proc. SPIE 7769, High and Low Concentrator Systems for Solar Electric Applications V, 776901 (20 September 2010); doi: 10.1117/12.869882

SPIE Event: SPIE Solar Energy + Technology, 2010, San Diego, California, United SPIE. States 


\section{PROCEEDINGS OF SPIE}

\section{High and Low Concentrator Systems for Solar Electric Applications V}

Lori E. Greene

Raed A. Sherif

Editors

3-4 August 2010

San Diego, California, United States

Sponsored and Published by

SPIE

Volume 7769 
The papers included in this volume were part of the technical conference cited on the cover and title page. Papers were selected and subject to review by the editors and conference program committee. Some conference presentations may not be available for publication. The papers published in these proceedings reflect the work and thoughts of the authors and are published herein as submitted. The publisher is not responsible for the validity of the information or for any outcomes resulting from reliance thereon.

Please use the following format to cite material from this book:

Author(s), "Title of Paper," in High and Low Concentrator Systems for Solar Electric Applications V, edited by Lori E. Greene, Raed A. Sherif, Proceedings of SPIE Vol. 7769 (SPIE, Bellingham, WA, 2010) Article CID Number.

ISSN 0277-786X

ISBN 9780819482655

Published by

SPIE

P.O. Box 10, Bellingham, Washington $98227-0010$ USA

Telephone +1 3606763290 (Pacific Time) · Fax +1 3606471445

SPIE.org

Copyright (C) 2010, Society of Photo-Optical Instrumentation Engineers

Copying of material in this book for internal or personal use, or for the internal or personal use of specific clients, beyond the fair use provisions granted by the U.S. Copyright Law is authorized by SPIE subject to payment of copying fees. The Transactional Reporting Service base fee for this volume is $\$ 18.00$ per article (or portion thereof), which should be paid directly to the Copyright Clearance Center (CCC), 222 Rosewood Drive, Danvers, MA 01923. Payment may also be made electronically through CCC Online at copyright.com. Other copying for republication, resale, advertising or promotion, or any form of systematic or multiple reproduction of any material in this book is prohibited except with permission in writing from the publisher. The CCC fee code is 0277-786X/10/\$18.00.

Printed in the United States of America.

Publication of record for individual papers is online in the SPIE Digital Library.

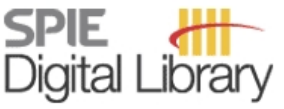

SPIEDigitalLibrary.org

Paper Numbering: Proceedings of SPIE follow an e-First publication model, with papers published first online and then in print and on CD-ROM. Papers are published as they are submitted and meet publication criteria. A unique, consistent, permanent citation identifier (CID) number is assigned to each article at the time of the first publication. Utilization of CIDs allows articles to be fully citable as soon they are published online, and connects the same identifier to all online, print, and electronic versions of the publication. SPIE uses a six-digit CID article numbering system in which:

- The first four digits correspond to the SPIE volume number.

- The last two digits indicate publication order within the volume using a Base 36 numbering system employing both numerals and letters. These two-number sets start with 00, 01, 02, 03, 04 , 05, 06, 07, 08, 09, OA, OB ... 0Z, followed by 10-1Z, 20-2Z, etc.

The CID number appears on each page of the manuscript. The complete citation is used on the first page, and an abbreviated version on subsequent pages. Numbers in the index correspond to the last two digits of the six-digit CID number. 


\section{Contents}

$\checkmark$ Conference Committee

SESSION 1 OPTICS FOR SOLAR CONCENTRATION

776902 Energy collection efficiency of low concentration holographic planar concentrators (Keynote Paper) [7769-01]

R. K. Kostuk, J. Castro, D. Zhang, The Univ. of Arizona (United States)

776903 New architecture for utility scale electricity from concentrator photovoltaics (Keynote Paper) [7769-02]

R. Angel, T. Connors, W. Davison, B. Olbert, S. Sivanandam, The Univ. of Arizona (United States)

776904 Lateral translation micro-tracking of planar micro-optic solar concentrator [7769-03]

J. M. Hallas, J. H. Karp, E. J. Tremblay, J. E. Ford, Univ. of California, San Diego (United States)

776905 New classes of maximum-concentration photovoltaic concentrators with liberal optical tolerance based on dual-mirror optics [7769-04]

A. Goldstein, J. M. Gordon, Ben-Gurion Univ. of the Negev (Israel)

\section{SESSION 2 NANO OPTICS AND MULTI-JUNCTION CELLS}

776907 Tin monosulfide thin films grown by atomic layer deposition using tin $\mathbf{2 , 4}$ pentandionate and hydrogen sulfide [7769-06]

J. Y. Kim, S. M. George, Univ. of Colorado at Boulder (United States)

776908 Design and performance of nanostructure-based luminescent solar concentrators [7769-07] G. V. Shcherbatyuk, R. H. Inman, R. Winston, S. Ghosh, Univ. of California, Merced (United States)

776909 InGaP/GaAs/InGaAs triple junction concentrators using bi-facial epigrowth [7769-08] P. Chiu, S. Wojtczuk, X. Zhang, D. Derkacs, C. Harris, D. Pulver, Spire Semiconductor, LLC (United States); M. Timmons, Consultant (United States)

7769 OA A high irradiance solar furnace for solar cell characterization and nanomaterial synthesis [7769-09]

D. Babai, D. Fevermann, J. M. Gordon, Ben-Gurion Univ. of the Negev (Israel)

\section{SESSION 3 CPV AND CSP SYSTEMS}

7769 OB Energy prediction of Amonix solar power plants (Invited Paper) [7769-10]

G. S. Kinsey, K. Stone, V. Garboushian, Amonix Inc. (United States) 
7769 OC Production and deployment of high performance CPV panels for the utility scale marketplace (Invited Paper) [7769-11]

A. Plesniak, G. Martins, J. Hall, The Boeing Co. (United States)

7769 OD Daily and seasonal performance of angularly dependent fixed mount dual aperture holographic planar concentrator photovoltaic modules [7769-12]

J. M. Russo, J. E. Castillo, E. D. Aspnes, Prism Solar Technologies, Inc. (United States);

R. K. Kostuk, The Univ. of Arizona (United States); G. Rosenberg, Prism Solar Technologies, Inc.

(United States)

\section{SESSION 4 RELIABILITY OF CPV: JOINT SESSION WITH CONFERENCE 7773}

7769 OF Benefits of metal reflective surfaces for concentrating solar applications [7769-15]

S. Braendle, Alanod-Solar (Germany)

7769 OG Advanced thermal management materials for concentrator photovoltaic arrays [7769-16]

C. Zweben, Consultant (United States)

\section{SESSION 5 MEASUREMENTS FOR CPV: JOINT SESSION WITH CONFERENCE 7773}

$7769 \mathrm{OH}$ Challenges in performance testing and energy rating of one-axis concentrator photovoltaic system [7769-17]

L. Leonard, M. Balma, M. Finot, Skyline Solar, Inc. (United States)

\section{POSTER SESSION}

7769 OK Simulation of point light concentration with parabolic trough collector [7769-20]

A. Danylyuk, M. Zettl, M. Lynass, GE Global Research (Germany)

$7769 \mathrm{OL}$ Low holographic concentration effects on CIGS [7769-21]

J. E. Castillo, J. M. Russo, Prism Solar Technologies, Inc. (United States); D. Zhang, R. K. Kostuk, The Univ. of Arizona (United States); G. A. Rosenberg, Prism Solar Technologies, Inc. (United States)

$77690 \mathrm{M}$ An energy analysis of a linear concentrating photovoltaic system with an active cooling system [7769-22]

T. L. Kerzmann, L. A. Schaefer, Univ. of Pittsburgh (United States)

Author Index

iv 


\title{
Conference Committee
}

\author{
Symposium Chair
}

Martha Symko-Davies, National Renewable Energy Laboratory (United States)

Conference Chairs

Lori E. Greene, University of California, Irvine (United States)

Raed A. Sherif, eSolar Inc. (United States)

Program Committee

Daniel J. Friedman, National Renewable Energy Laboratory (United States)

Vahan Garboushian, Amonix Incorporated (United States)

Cheryl E. Kennedy, National Renewable Energy Laboratory (United States)

Adam P. Plesniak, Amonix Incorporated (United States)

Kaitlyn VanSant, National Renewable Energy Laboratory (United States)

\section{Session Chairs}

1 Optics for Solar Concentration

Adam P. Plesniak, Amonix Incorporated (United States)

2 Nano Optics and Multi-junction Cells

Geoffrey S. Kinsey, Amonix Incorporated (United States)

3 CPV and CSP Systems

Roger P. Angel, The University of Arizona (United States)

$4 \quad$ Reliability of CPV: Joint Session with Conference 7773

Raed A. Sherif, eSolar Inc. (United States)

5 Measurements for CPV: Joint Session with Conference 7773

Takuya Doi, National Institute of Advanced Industrial Science and Technology (Japan) 
Downloaded From: https://www.spiedigitallibrary.org/conference-proceedings-of-spie on 26 Apr 2023

Terms of Use: https://www.spiedigitallibrary.org/terms-of-use 